\title{
Evaluation on Influences of Inertial Mass on Seismic Responses and Structure-soil Interactions of Pile-soil-piers
}

\section{Wen XIE ( $\nabla$ xwjshs@163.com)}

Ningbo University https://orcid.org/0000-0002-5231-5173

\section{Limin Sun}

Tongji University College of Civil Engineering

Tiantao He

Ningbo Municipal Facilities Center

\section{Research Article}

Keywords: Pile-soil-pier, inertial mass, seismic responses, inertial effects, pile group effects, shaking table tests

Posted Date: March 17th, 2021

DOI: https://doi.org/10.21203/rs.3.rs-308796/v1

License: (c) (i) This work is licensed under a Creative Commons Attribution 4.0 International License. Read Full License

Version of Record: A version of this preprint was published at Bulletin of Earthquake Engineering on April 11th, 2021. See the published version at https://doi.org/10.1007/s10518-021-01095-z. 


\section{Abstract}

This research is to assess the influences of the inertial mass from the girder on the dynamic characteristic, dynamic response, and structure-soil interaction of a pile-soil-pier subsystem in a scalemodel of a cable-stayed bridge. Therefore, both connection configurations between the pile-soil-pier and girder, including the sliding and fixed connections, were designed to present various inertial mass from the superstructure delivered to the pile-soil-pier. The pile-soil-pier supported by a $3 \times 3$ pile-group in mixed soil placed in a shear box was tested using shaking tables. The dynamic characteristics, seismic responses, inertial interactions, and pile group effects of the pile-soil-pier between the sliding and fixed connections were analyzed under three input motions with different shaking amplitudes. These results showed that more inertial mass from the girder significantly increased the reinforcement strain and bending moment at the column bottom and pile top, displacement at the column top, inertial interaction effects, and pile group effects of the pile-soil-pier due to the sliding connection changing to the fixed connection. The inertial mass increment from the girder noticeably decreased the peak accelerations of the column of the pile-soil-pier when subjected to three input motions with different amplitudes. However, the inertial mass insignificantly affected the accelerations of the pile and free-soil. Therefore, the corresponding kinematic interaction effects were almost unaffected by the inertial mass. Additionally, the evident pile group effects were observed in the sliding and fixed connections between the pile-soil-pier and girder. 24 The numerical model could approximately reproduce the macroscopic seismic responses of the pile-soil-piers with sliding and fixed connections and capture the typical response variations induced by the connection configuration change.

\section{Full Text}

This preprint is available for download as a PDF.

\section{Figures}

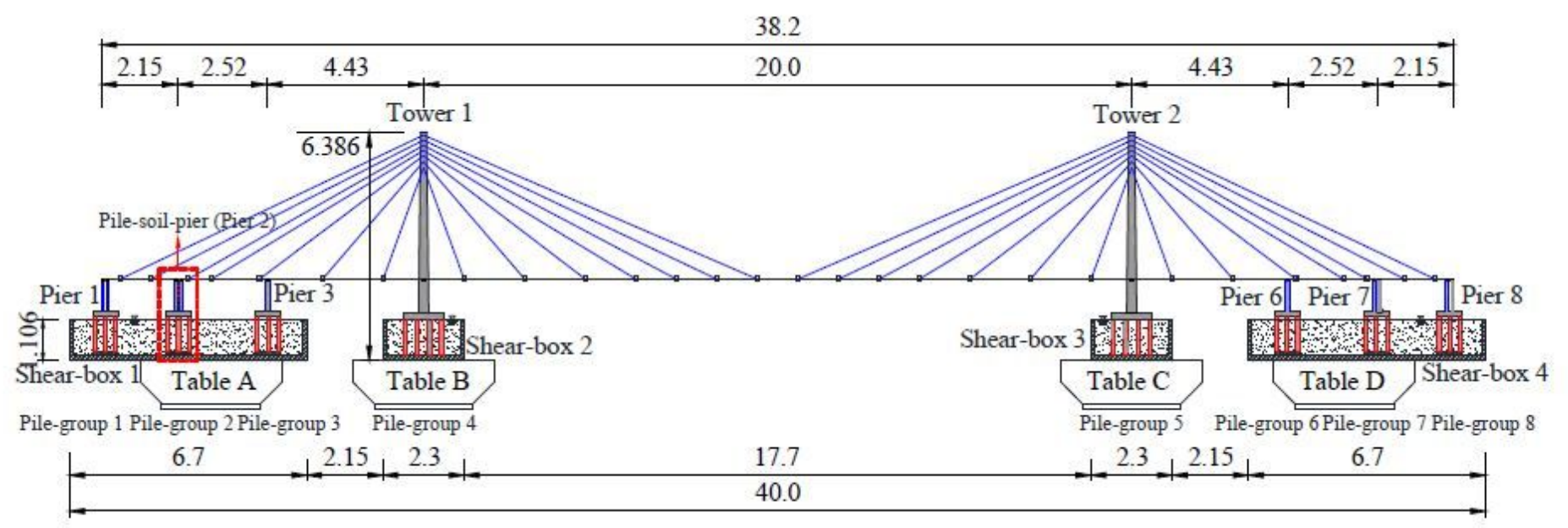

Figure 1 
Elevation view of cable-stayed bridge model (Units: $\mathrm{m}$ )

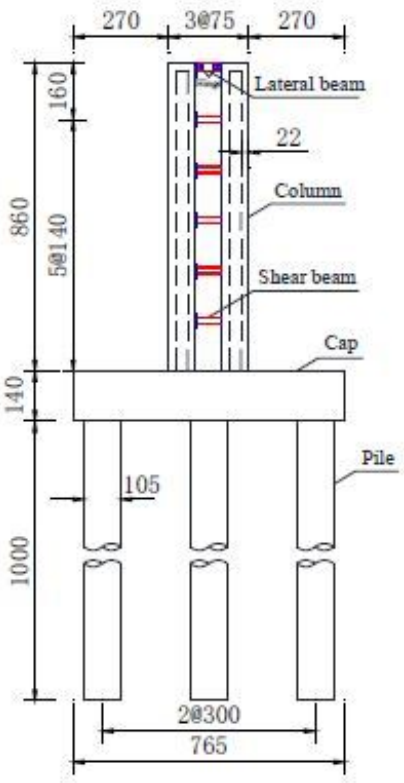

(a) Pile-soil-pier (Pier 2)

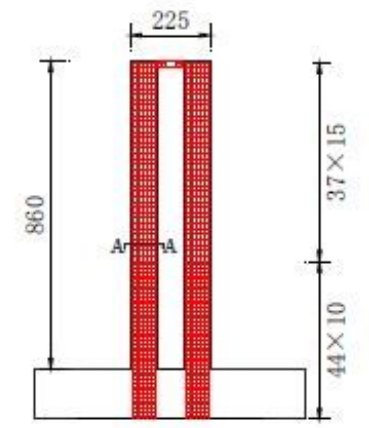

(b) Pier column reinforcement

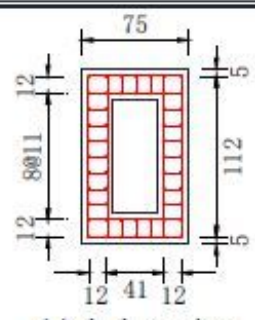

(c) A-A section
Note: Dimension units are millimeter (mm).

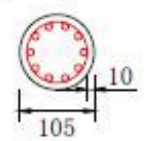

(d) Pile B-B section

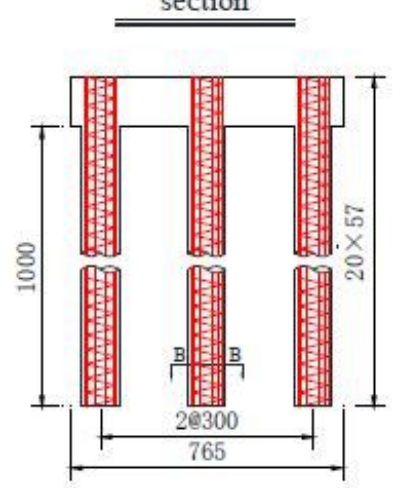

(e) Pile group reinforcement

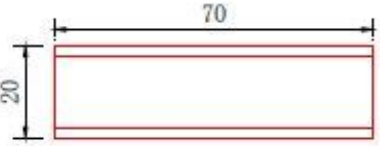

(g) Elevation view of shear beams $\longrightarrow$ $\stackrel{+}{\square}$ (h) Cross section of shear beams

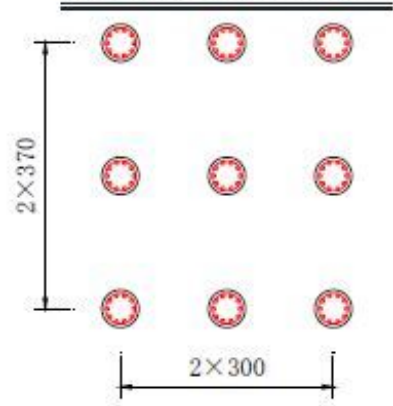

(f) Plan elevation of pile

Figure 2

Size dimensions and rebar arrangements of pile-soil-pier 


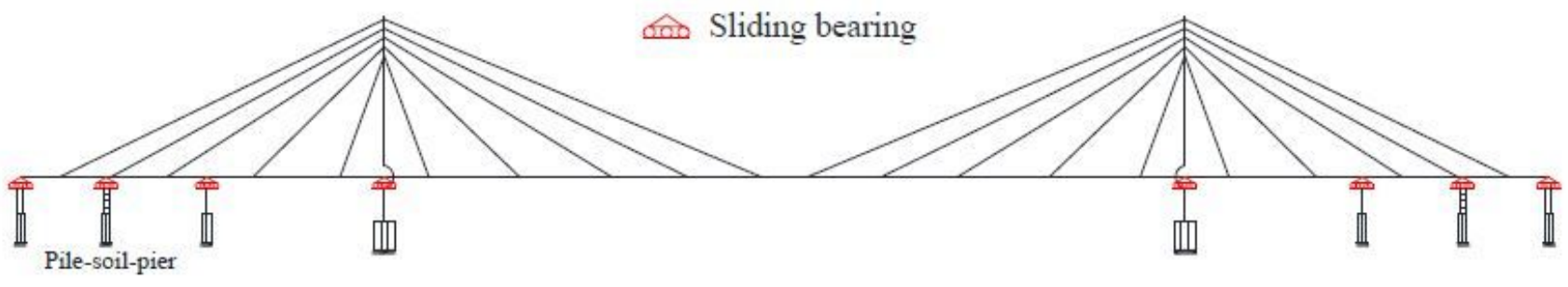

(a) Schematic of sliding connections between the pile-soil-pier and girder in the floating structural system

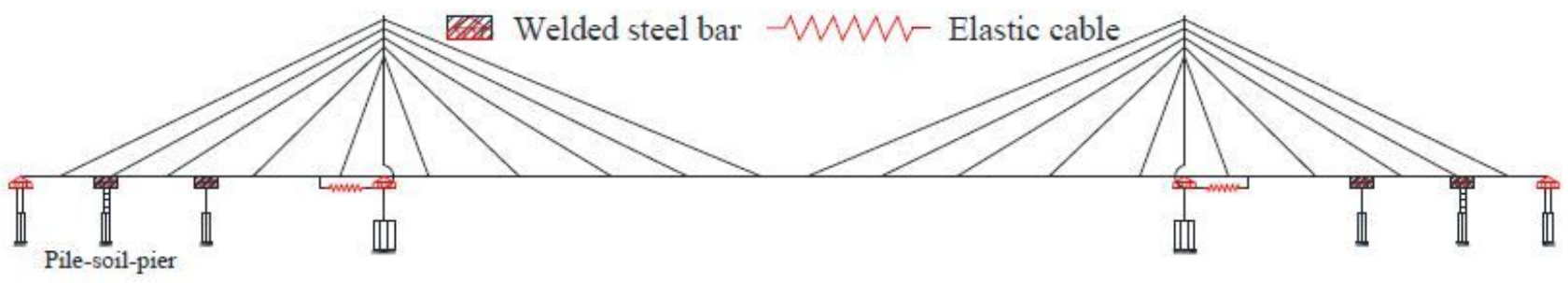

(b) Schematic of fixed connections between the pile-soil-pier and girder in the supporting pier structural system

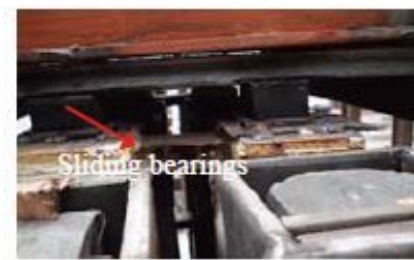

(c) Sliding connections between pile-soil-pier and girder

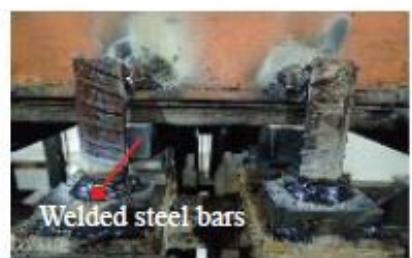

(d) Fixed connections between pile-soil-pier and girder

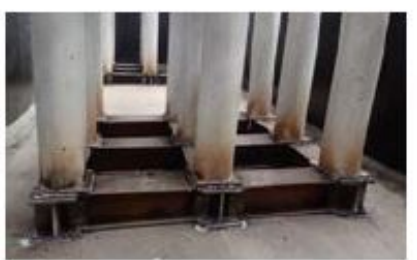

(e) Connections between pile tips and shear box

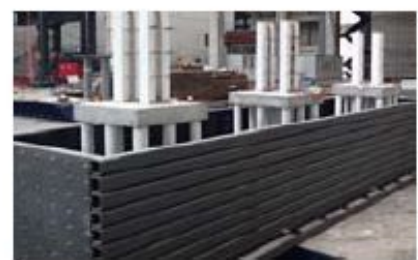

(f) Connections between shear box and table

\section{Figure 3}

Connection configurations between the pile-soil-pier and girder 

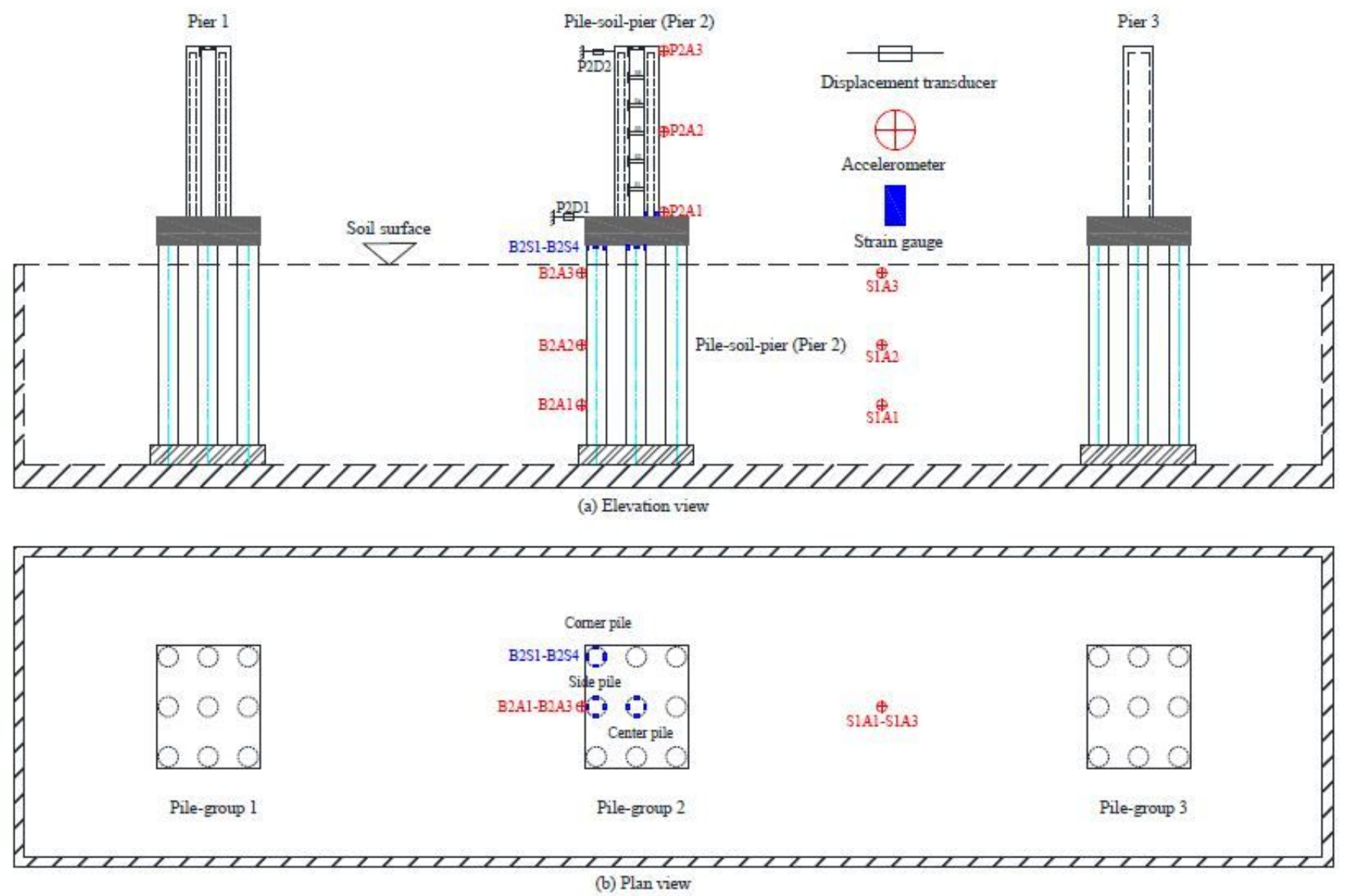

Figure 4

Instrumentations of pile-soil-pier in Shear-box 1

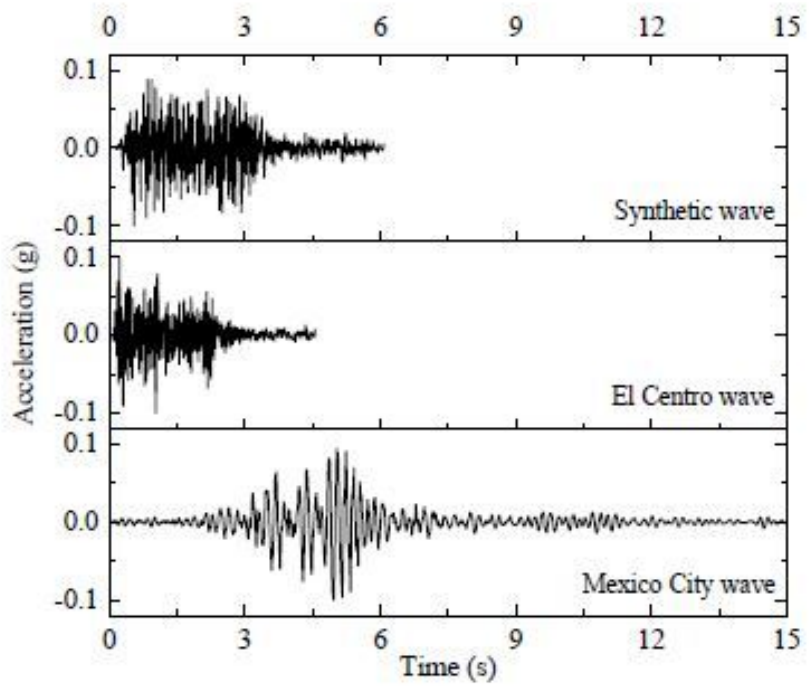

(a) Acceleration histories

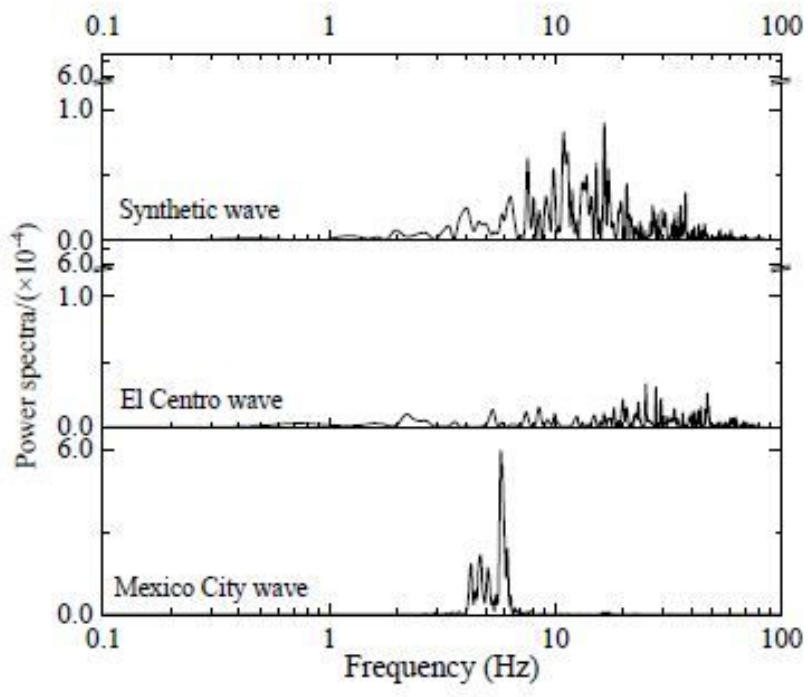

(b) Frequency spectra

Figure 5 
Acceleration histories and frequency spectra of three input motions

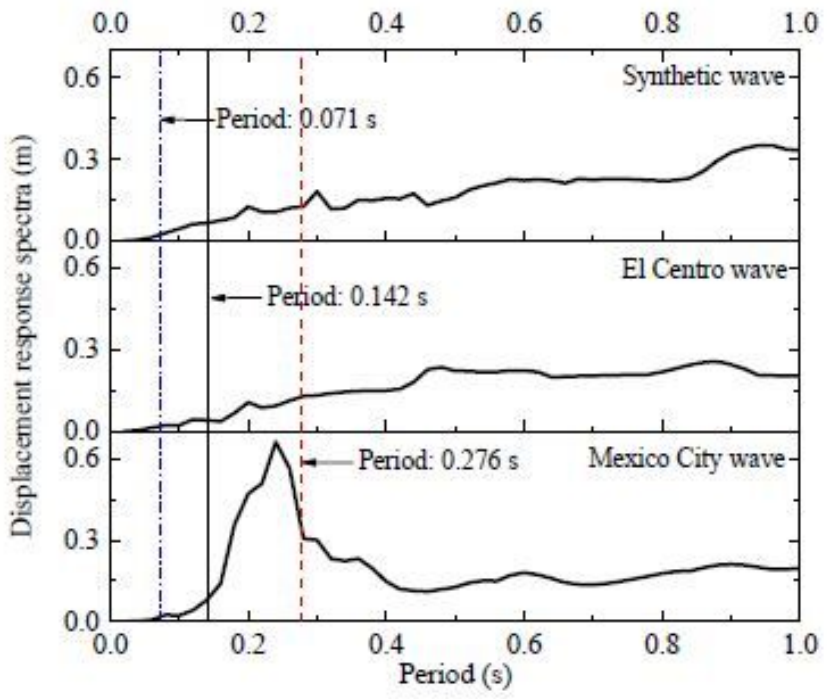

(a) Displacement spectra

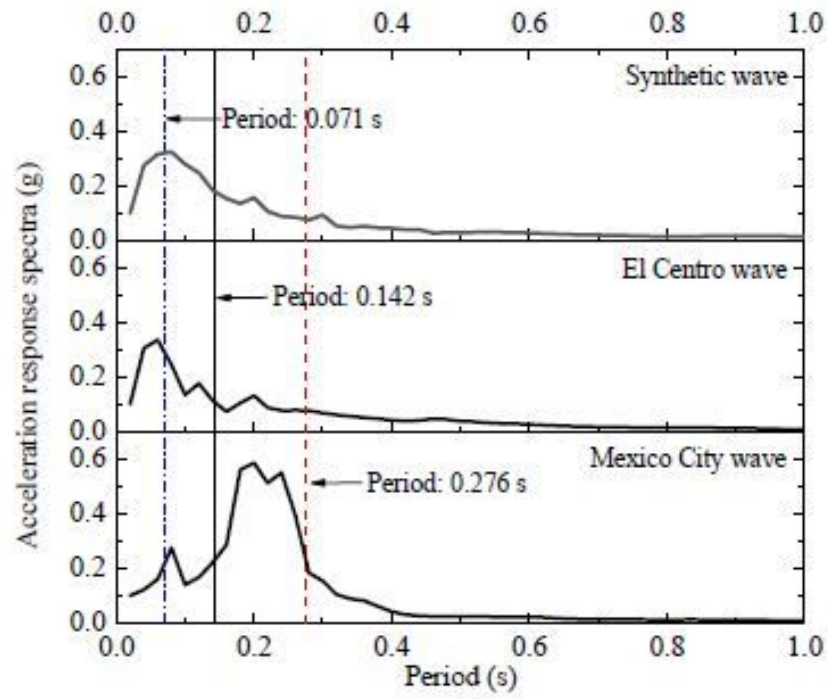

(b) Acceleration spectra

\section{Figure 6}

Displacement and acceleration spectra of three input motions

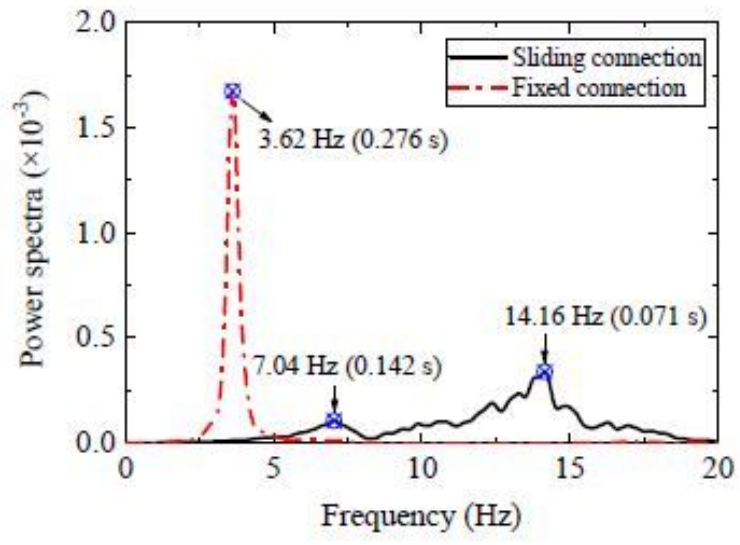

(a) Column top

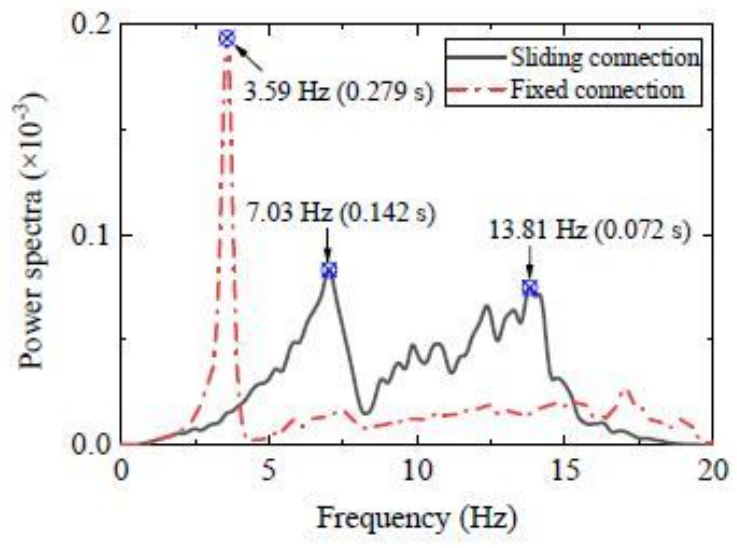

(b) Column bottom

\section{Figure 7}

Dominant frequencies of pile-soil-piers with sliding and fixed connections 


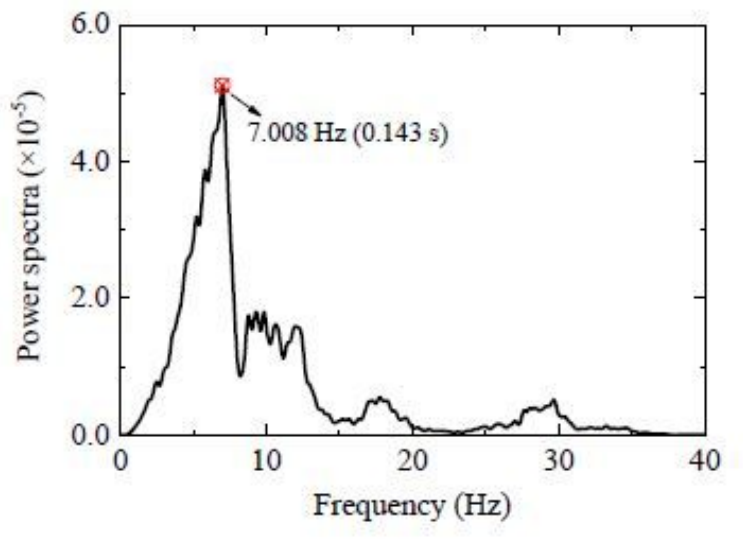

(a) Pile-soil-pier with sliding connections

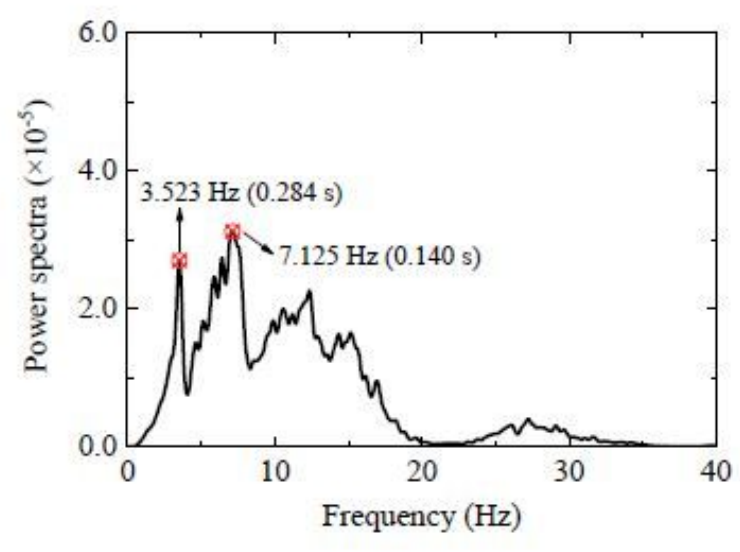

(b) Pile-soil-pier with fixed connections

\section{Figure 8}

Frequency characteristics of free-soil in Shear-box 1 for pile-soil-piers with sliding and fixed connections

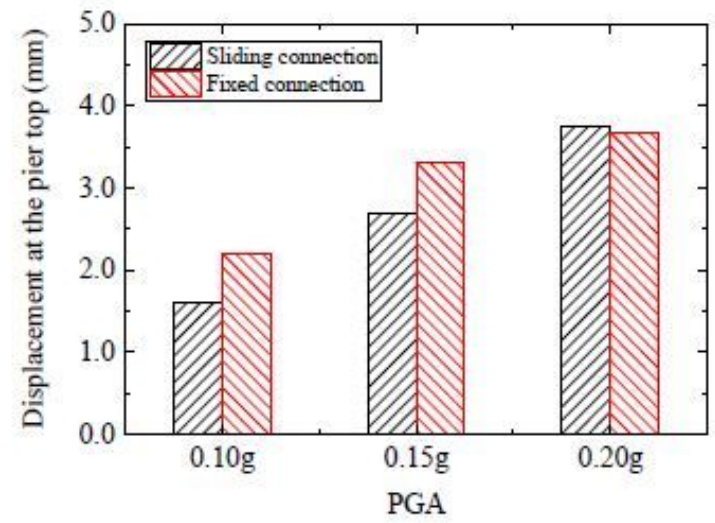

(a) Column top

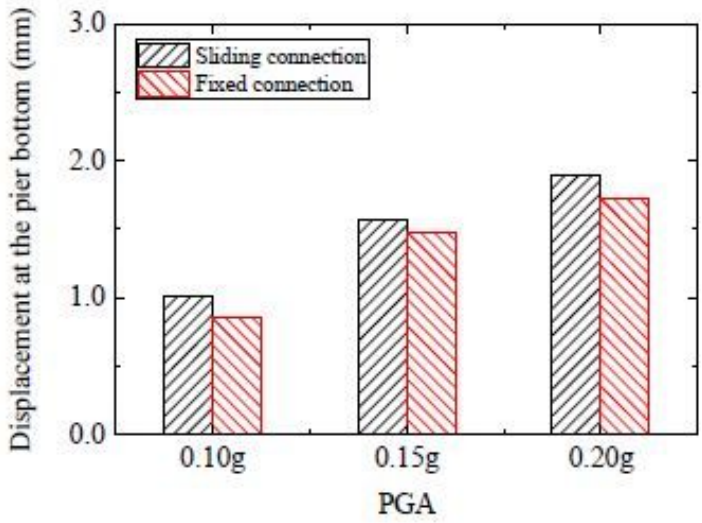

(b) Column bottom

\section{Figure 9}

Peak displacements of the column of the pile-soil-pier with sliding and fixed connections under the synthetic wave 


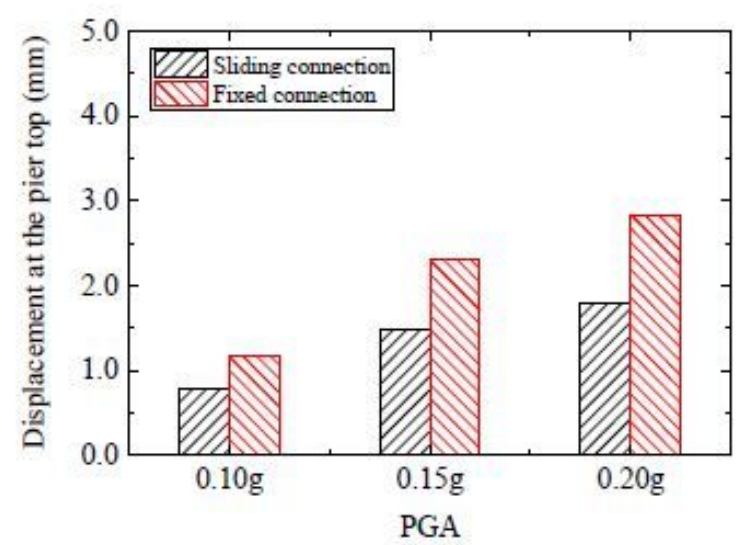

(a) Column top

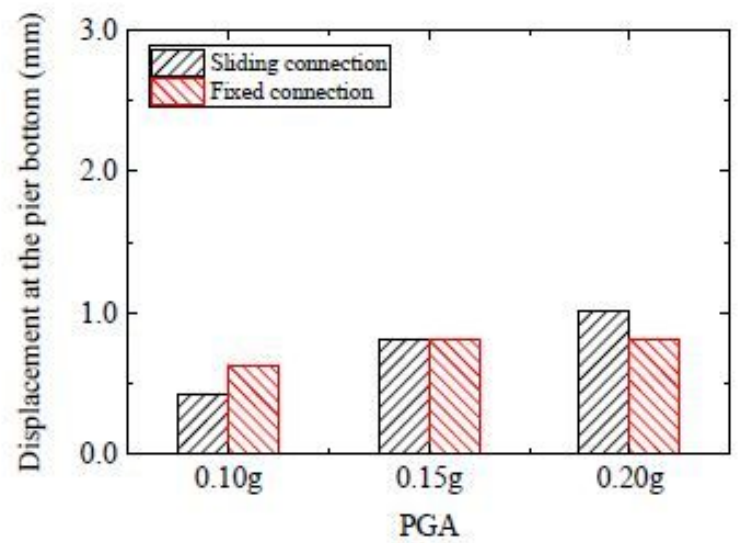

(b) Column bottom

\section{Figure 10}

Peak displacements of the column of the pile-soil-pier with sliding and fixed connections under the El Centro wave

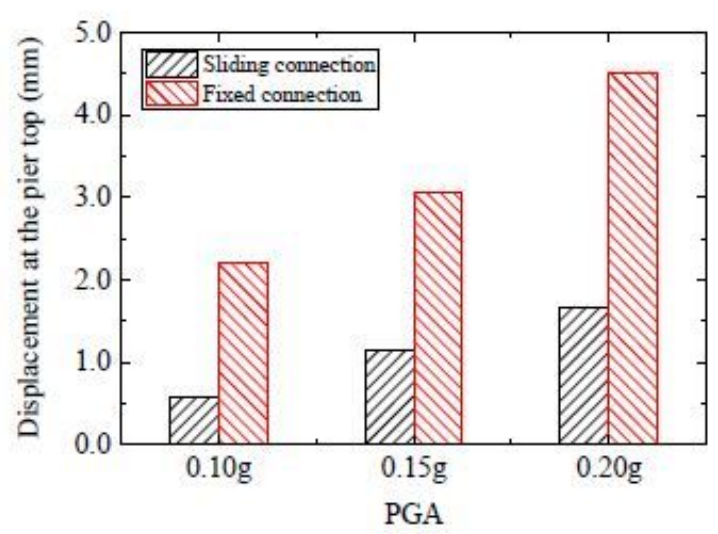

(a) Column top

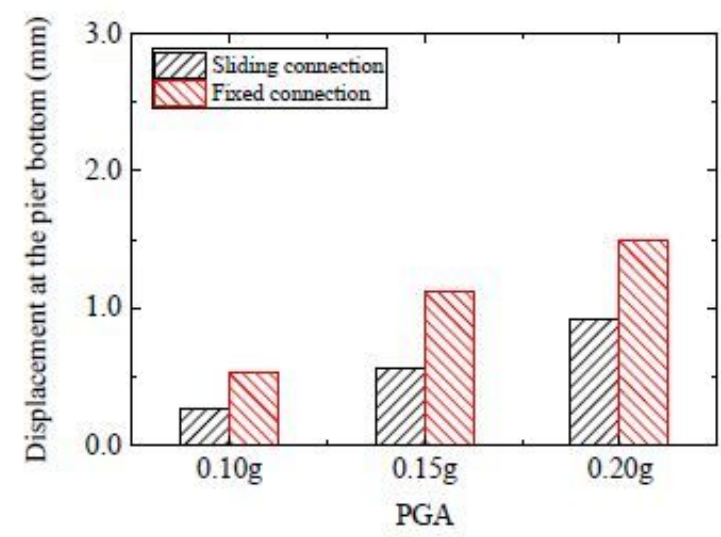

(b) Column bottom

\section{Figure 11}

Peak displacements of the column of pile-soil-pier with sliding and fixed connections under the Mexico City wave 


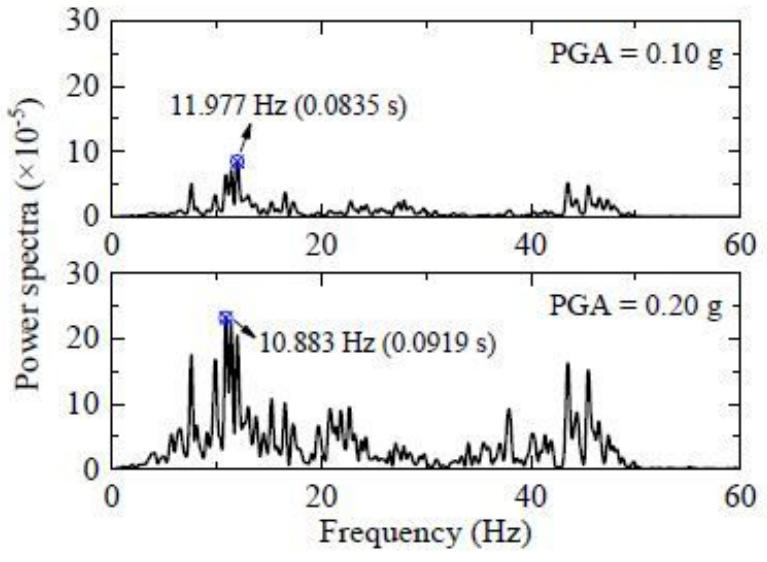

(a) Pile-soil-pier with sliding connections

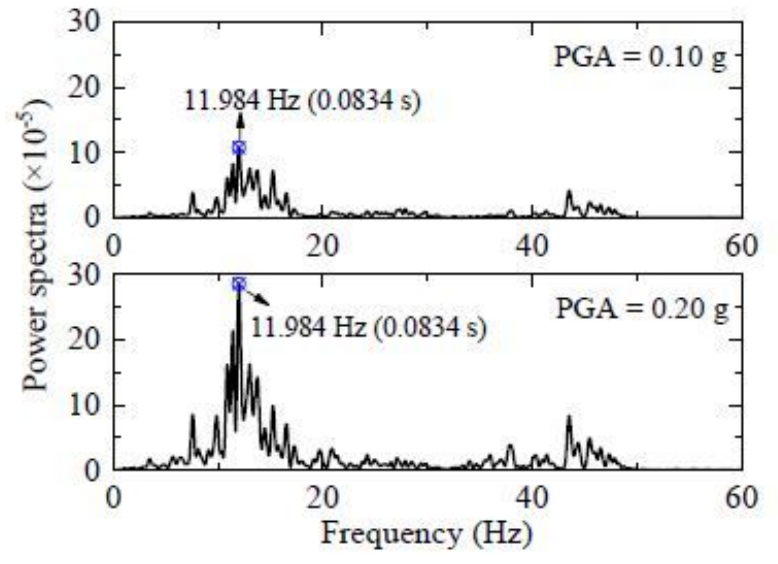

(b) Pile-soil-pier with fixed connections

\section{Figure 12}

Dynamic characteristics of the free-soil of the pile-soil-pier with sliding and fixed connections under the synthetic wave
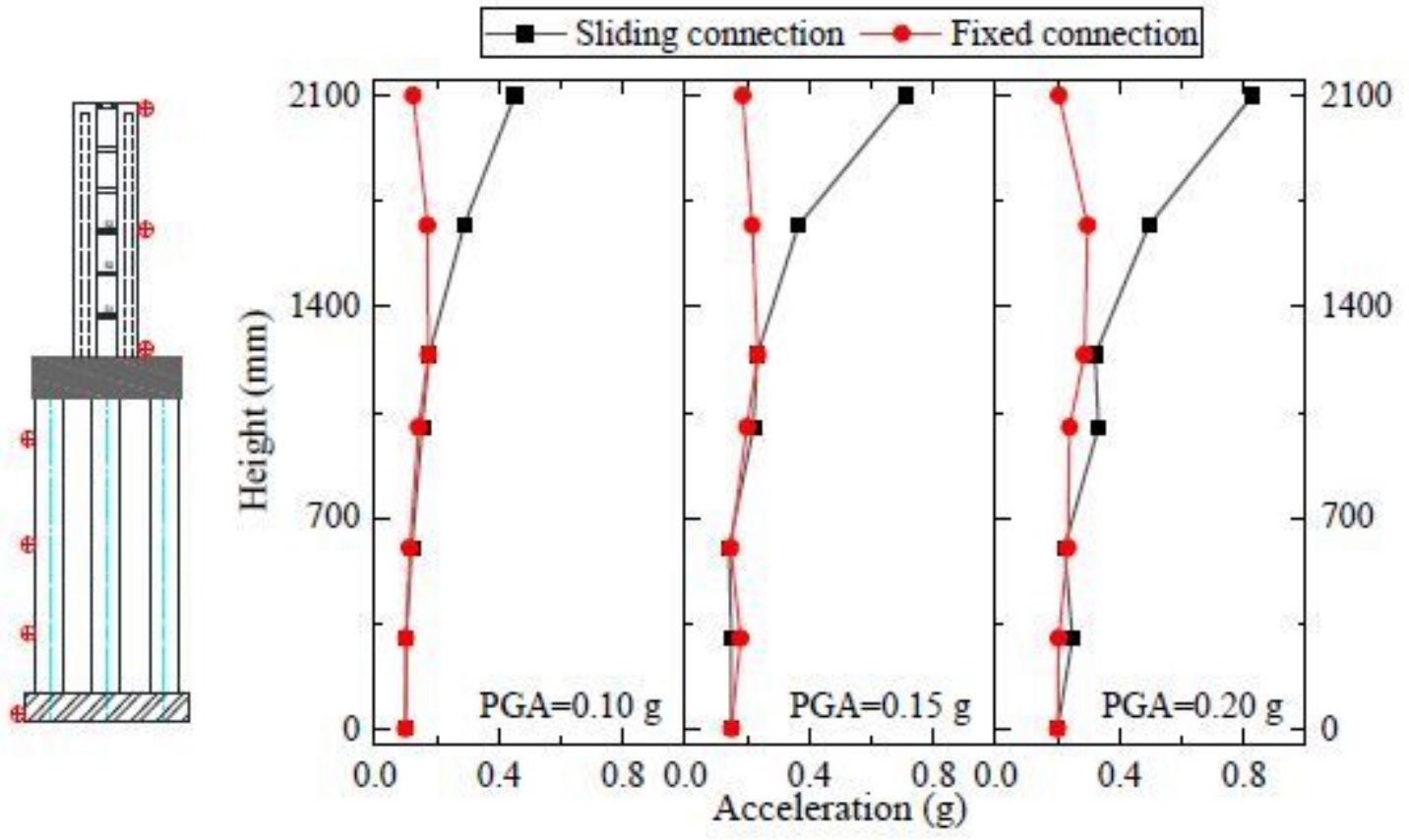

Figure 13

Comparisons of peak accelerations of the column and pile between pile-soil-piers with sliding and fixed connections under the synthetic wave 


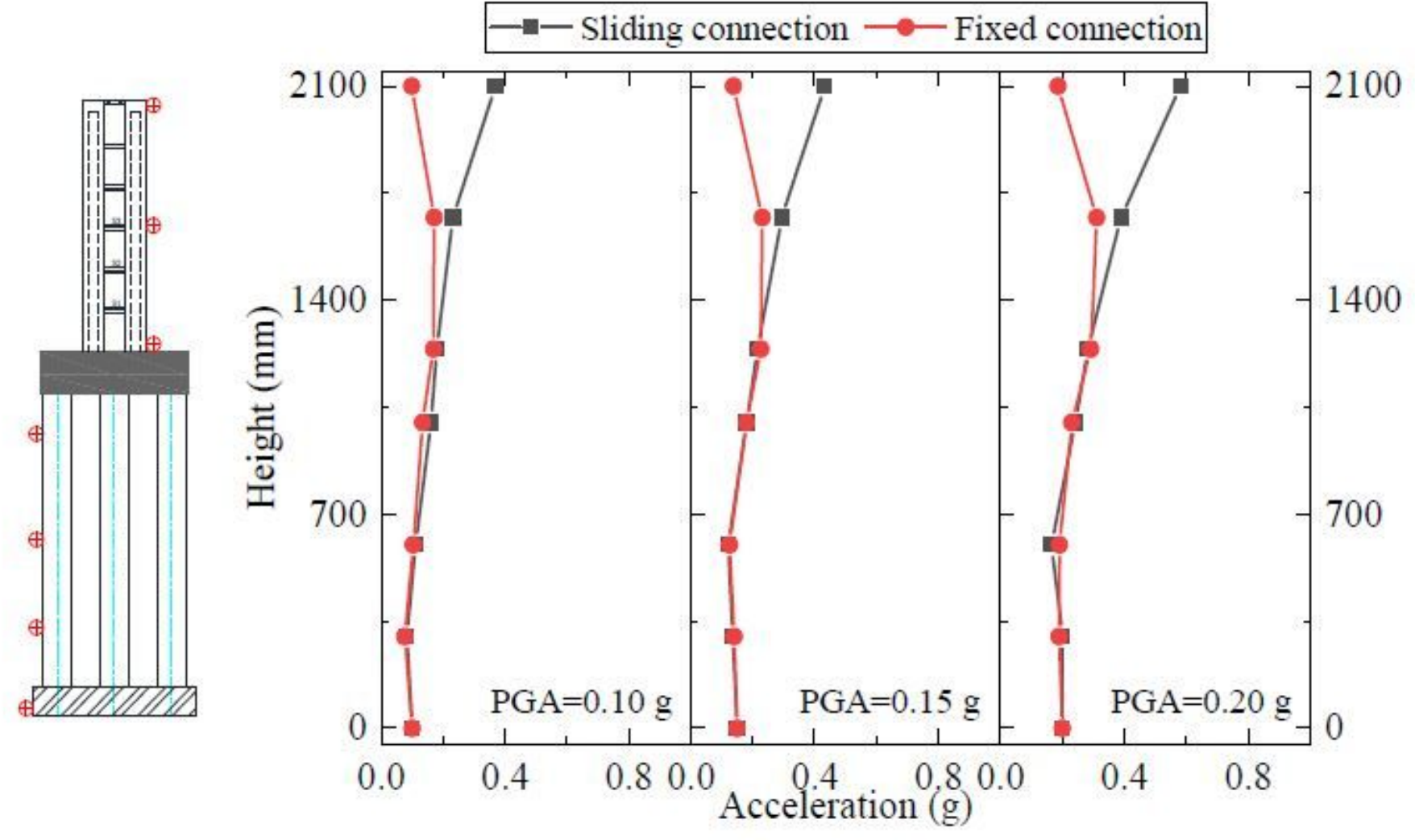

Figure 14

Comparisons of peak accelerations of the column and pile between pile-soil-piers with sliding and fixed connections under the El Centro wave 


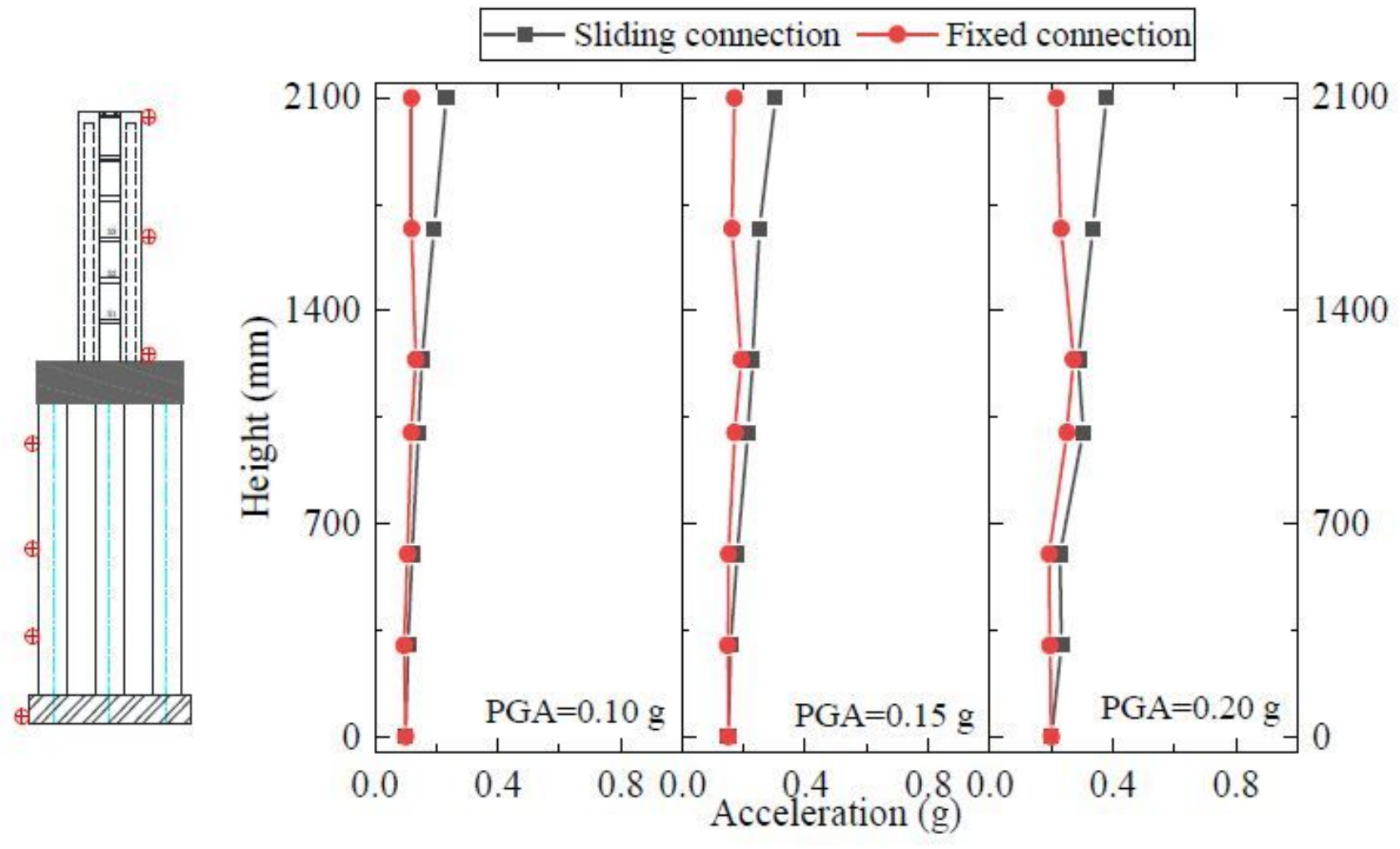

Figure 15

Comparisons of peak accelerations of the column and pile between pile-soil-piers with sliding and fixed connections under the Mexico City wave

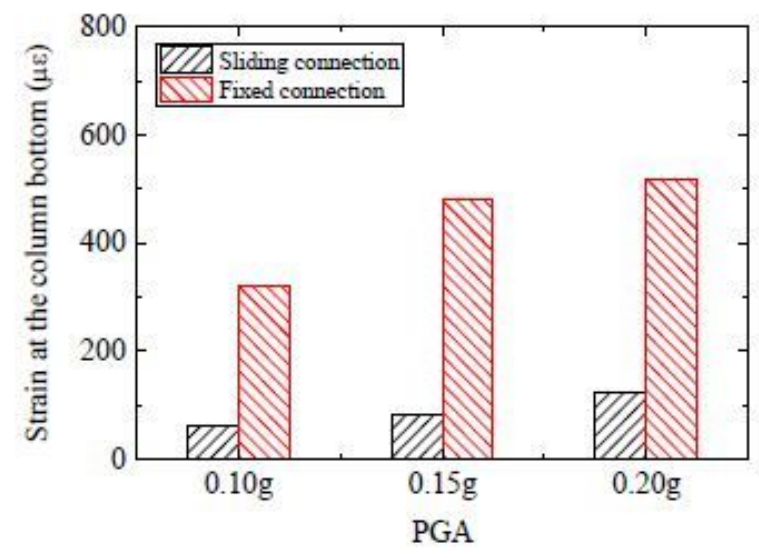

(a) Column bottom

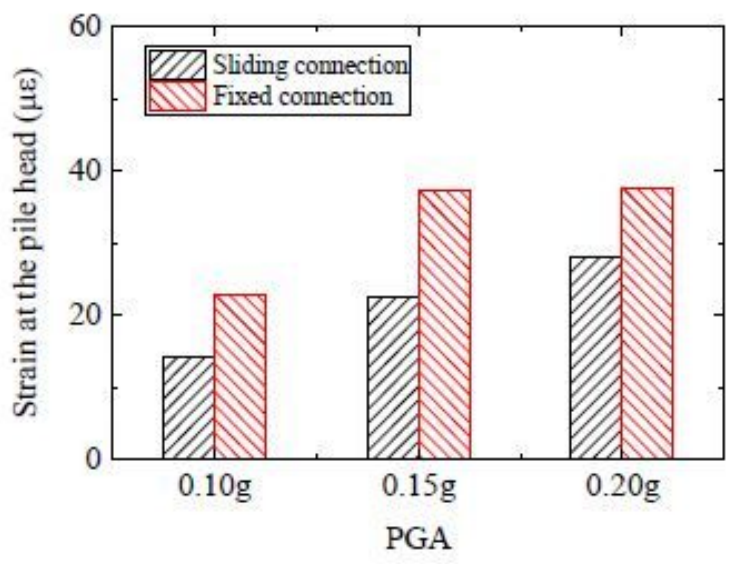

(b) Pile head

Figure 16

Comparisons of reinforcement strain between pile-soil-piers with sliding and fixed connections under the synthetic wave 


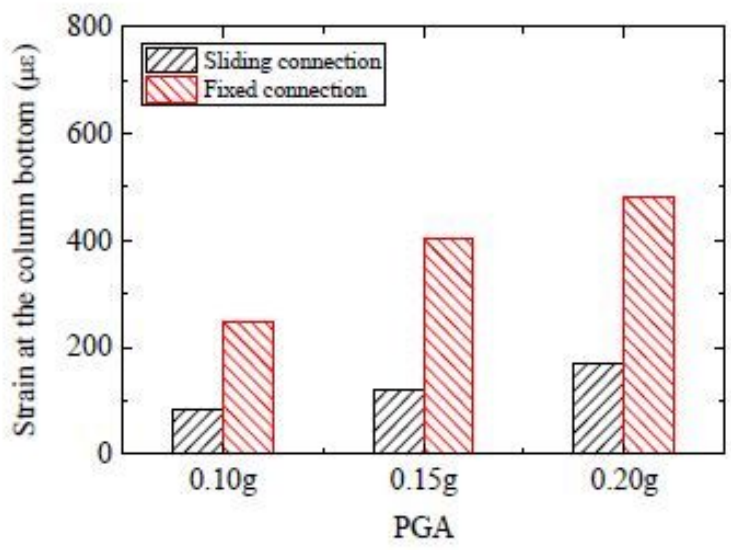

(a) Column bottom

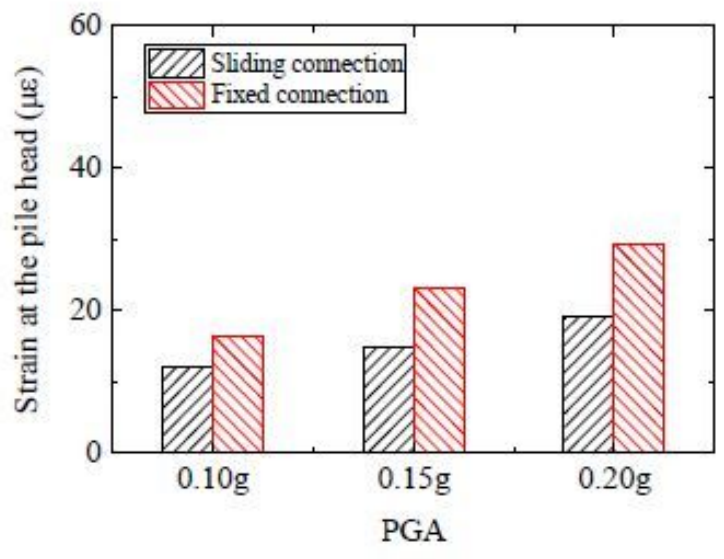

(b) Pile head

\section{Figure 17}

Comparisons of reinforcement strain between pile-soil-piers with sliding and fixed connections under the El Centro wave

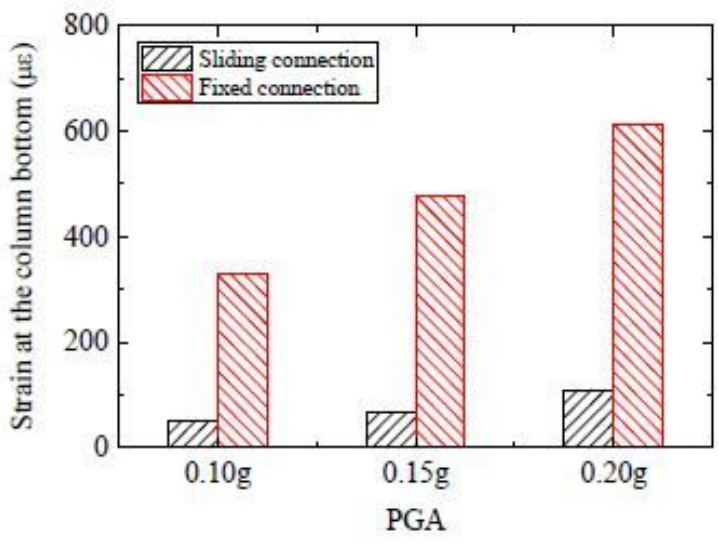

(a) Column bottom

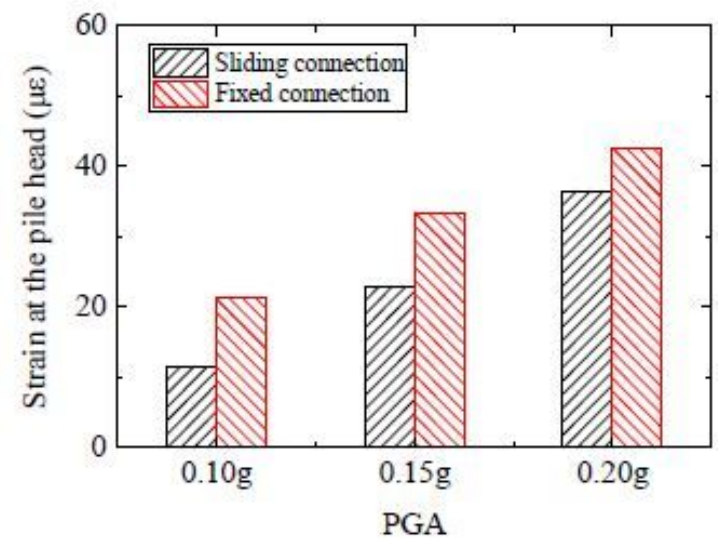

(b) Pile head

Figure 18

Comparisons of reinforcement strain between pile-soil-piers with sliding and fixed connections under the Mexico City wave 
Mexico City wave

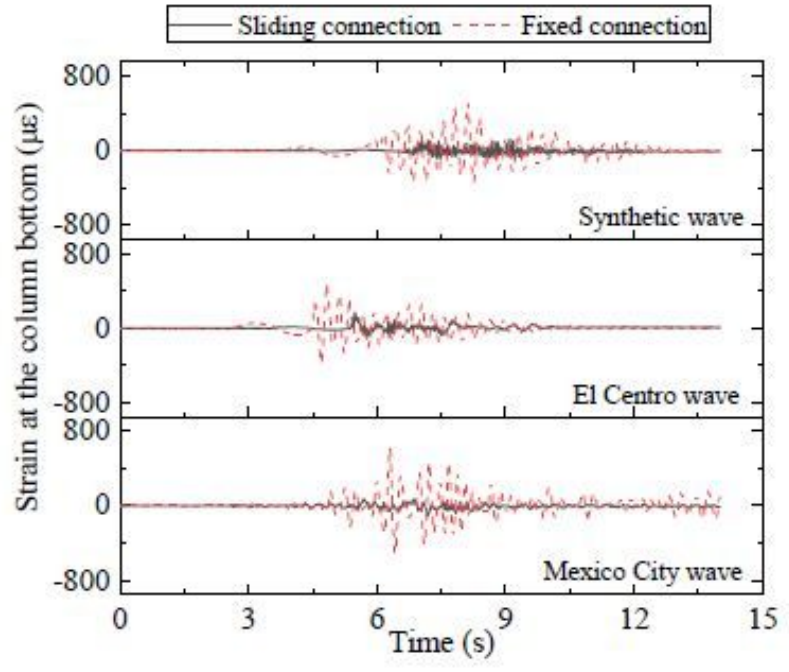

(a) Column bottom

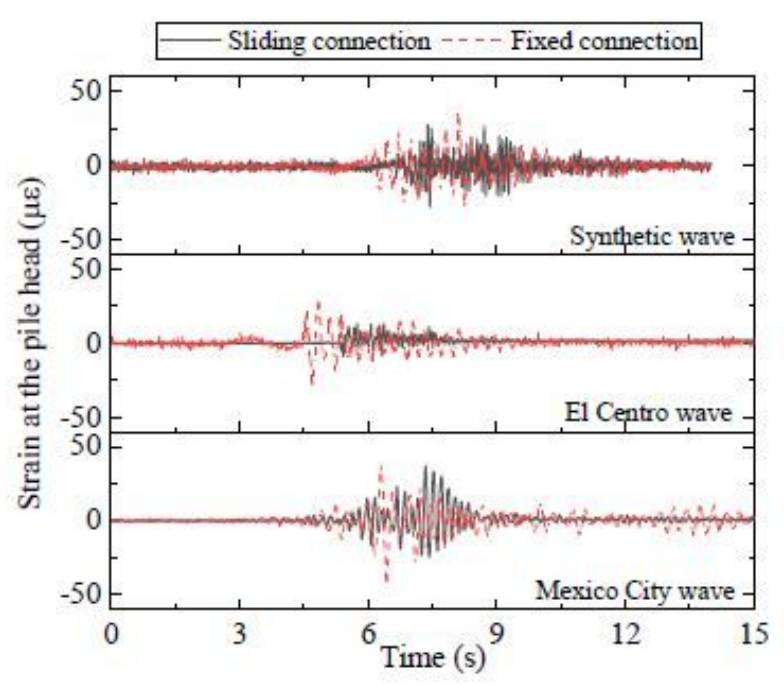

(b) Pile head

\section{Figure 19}

Reinforcement strain histories of pile-soil-piers with sliding and fixed connections under three input motions with $0.20 \mathrm{~g}$

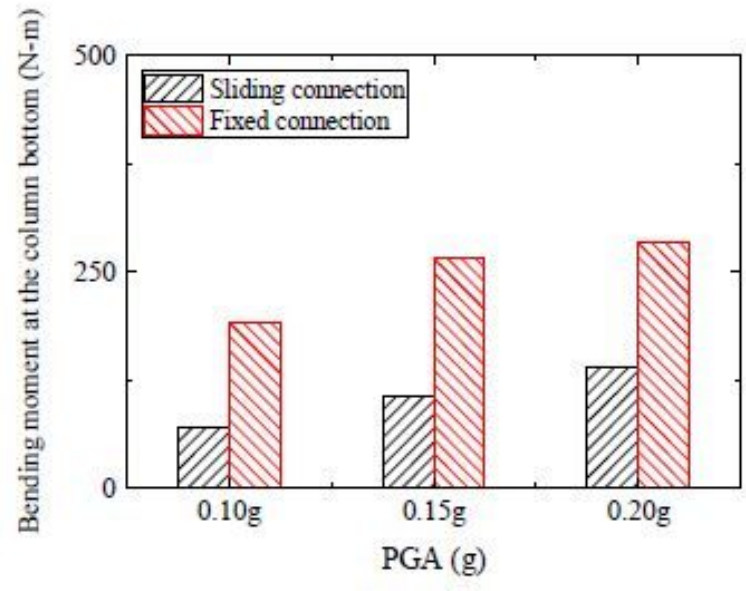

(a) Column bottom

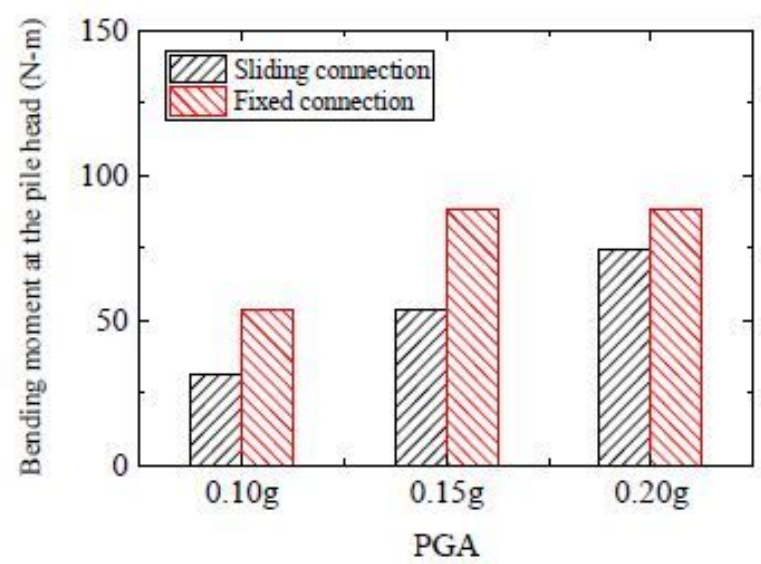

(b) Pile head

\section{Figure 20}

Comparisons of bending moment demands between pile-soil-piers with sliding and fixed connections under the synthetic wave 


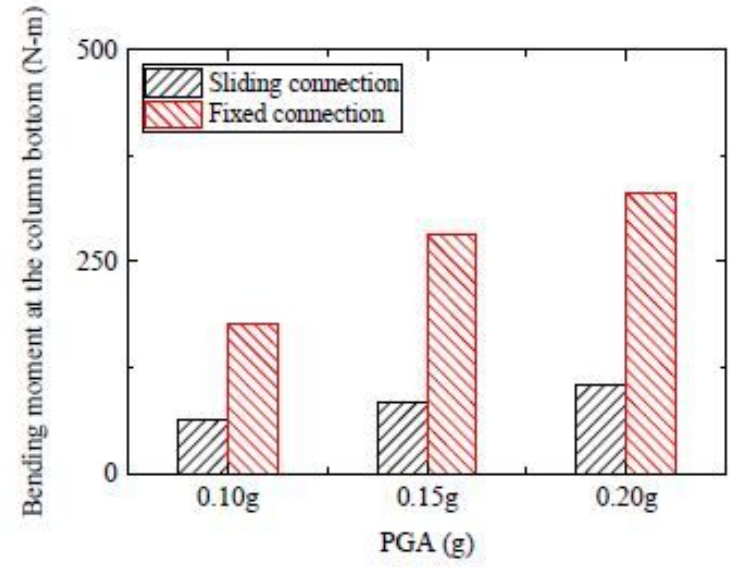

(a) Column bottom

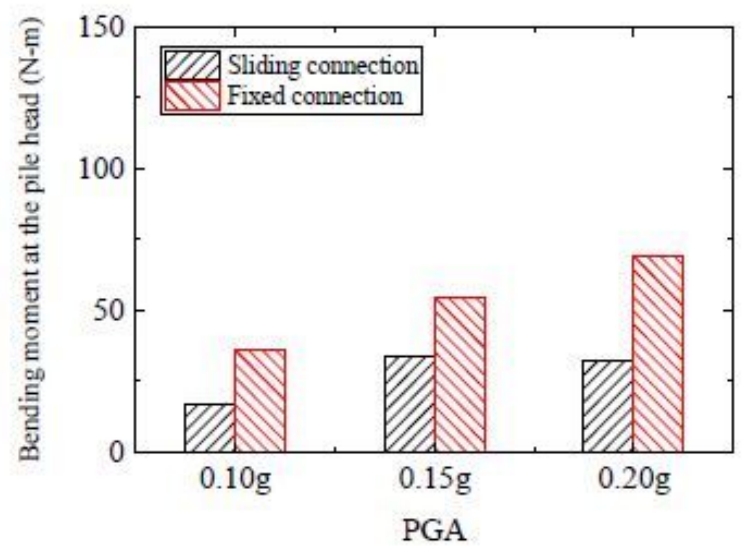

(b) Pile head

\section{Figure 21}

Comparisons of bending moment demands between pile-s 388 oil-piers with sliding and fixed connections under the El Centro wave

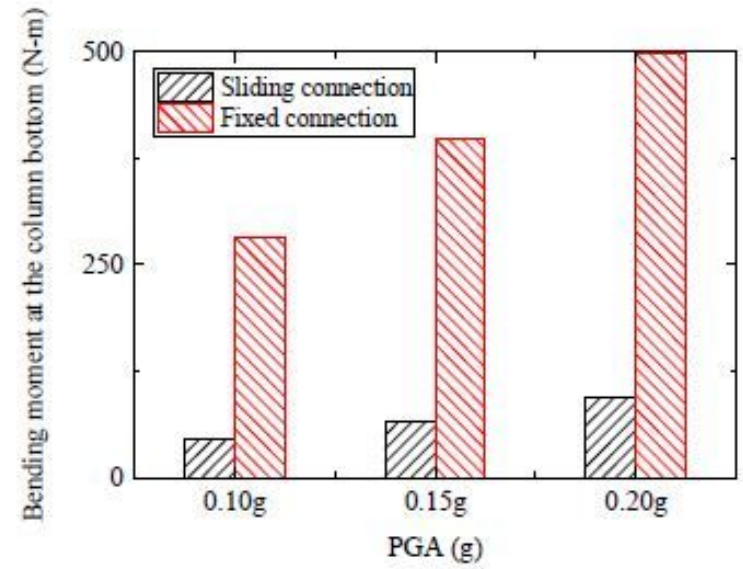

(a) Column bottom

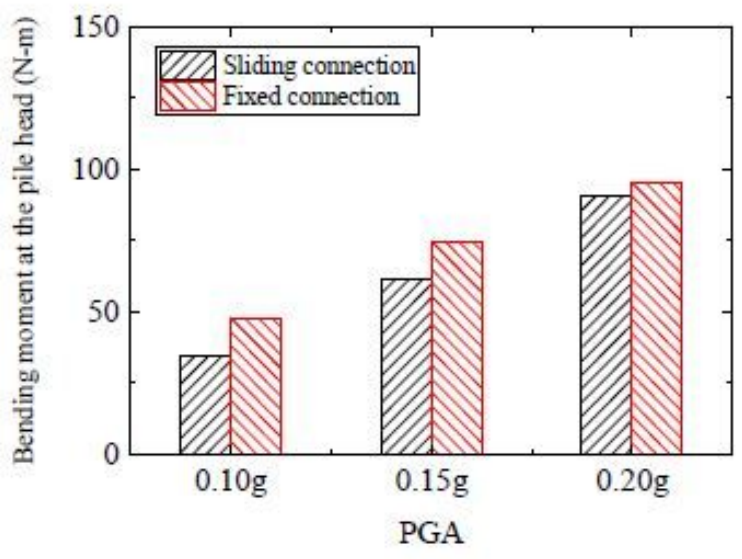

(b) Pile head

\section{Figure 22}

Comparisons of bending moment demands between pile-soil-piers with sliding and fixed connections under the Mexico City wave 


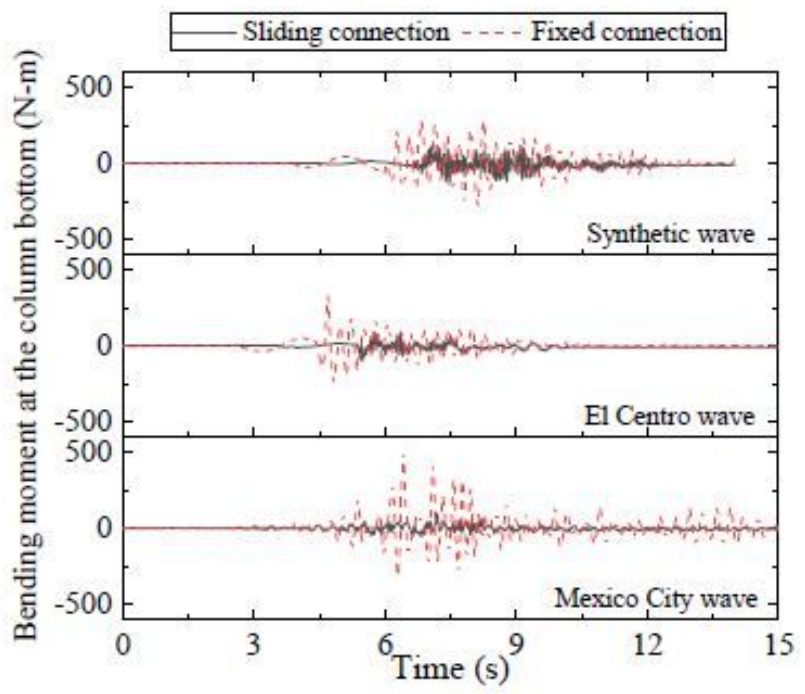

(a) Column bottom

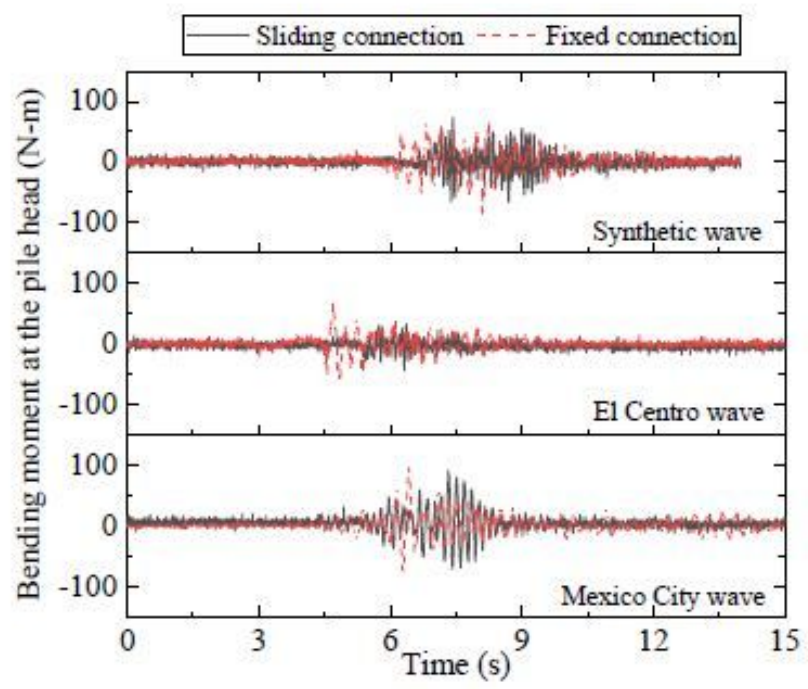

(b) Pile head

\section{Figure 23}

Comparisons of bending moment demands between pile-soil-piers with sliding and fixed connections under input motions with $0.20 \mathrm{~g}$ 


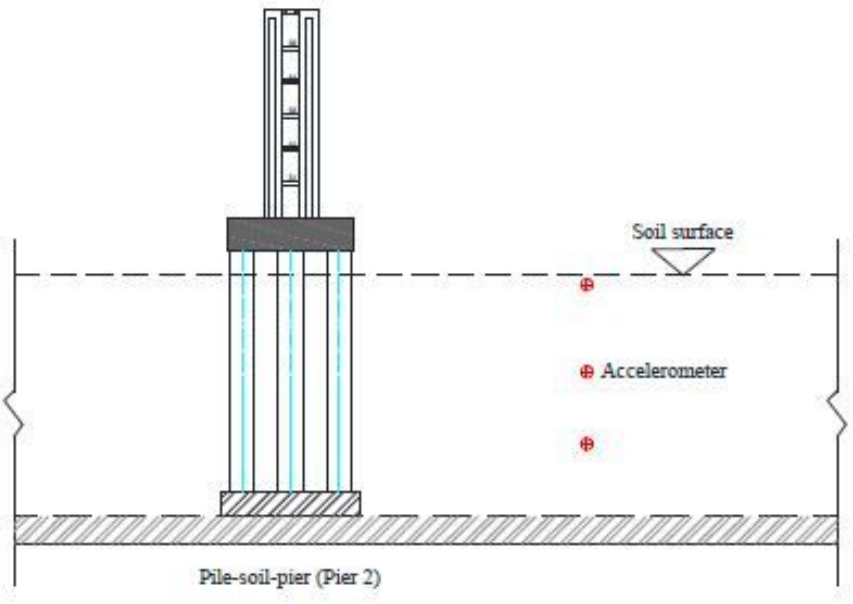

(a) Accelerometers arrangement

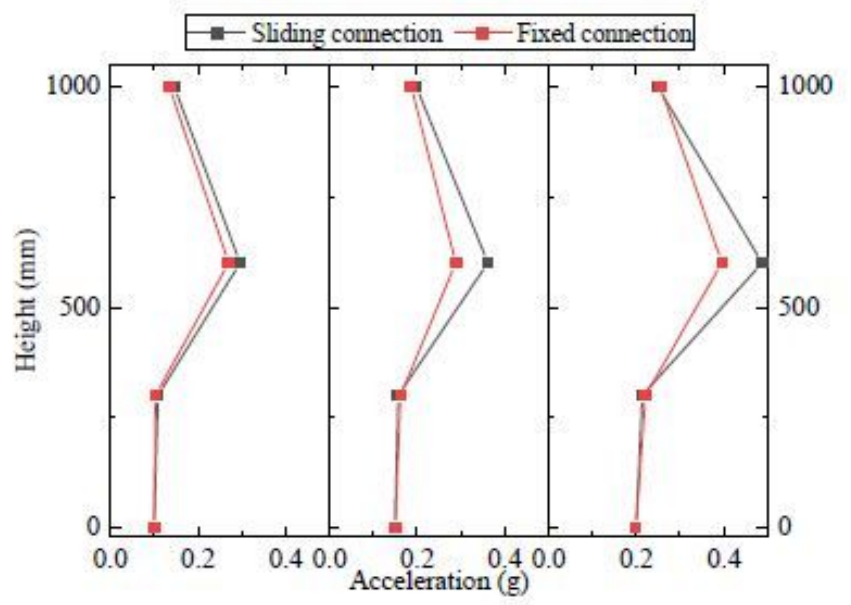

(c) El Centro wave

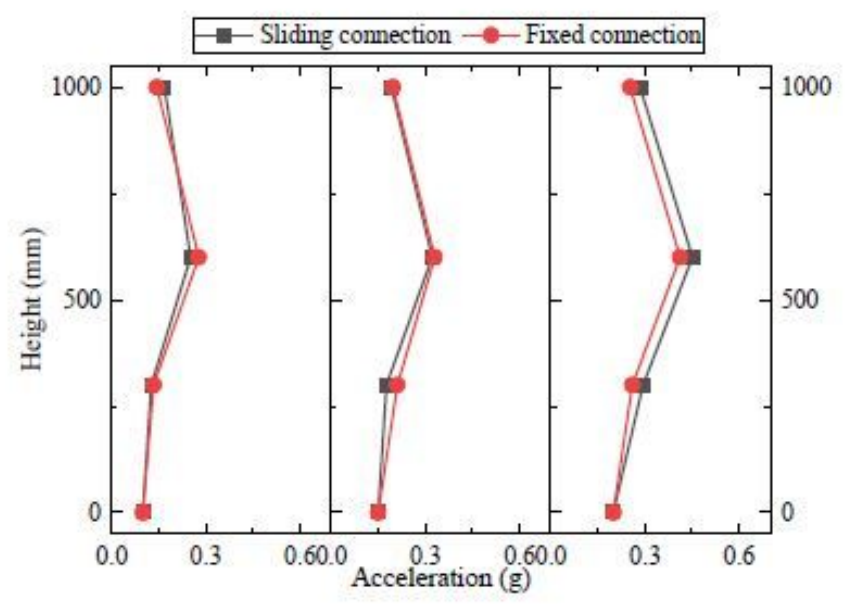

(b) synthetic wave

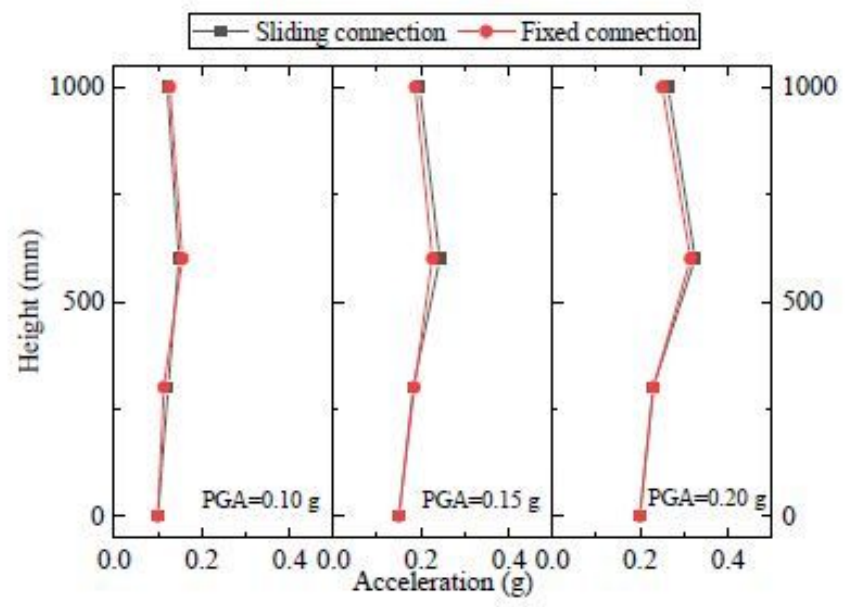

(d) Mexico City wave

Figure 24

Comparisons of the peak acceleration of the 415 free-soil between pile-soil-piers with sliding and fixed connections under three input motions 


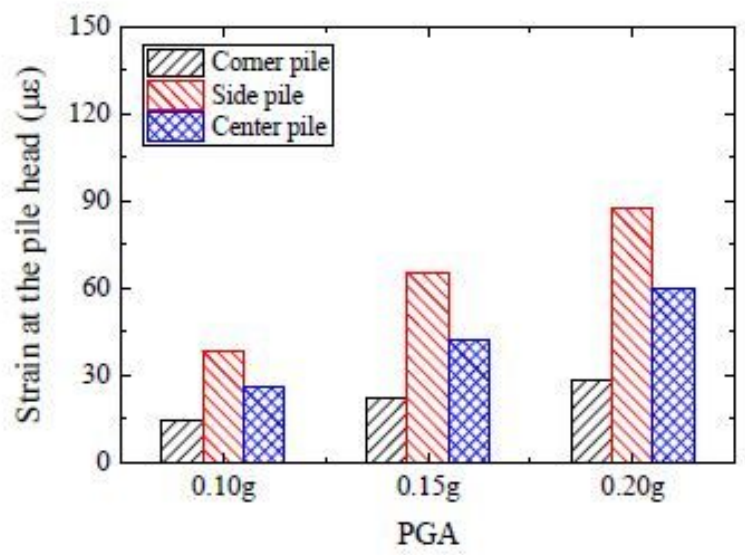

(a) Sliding connection configuration

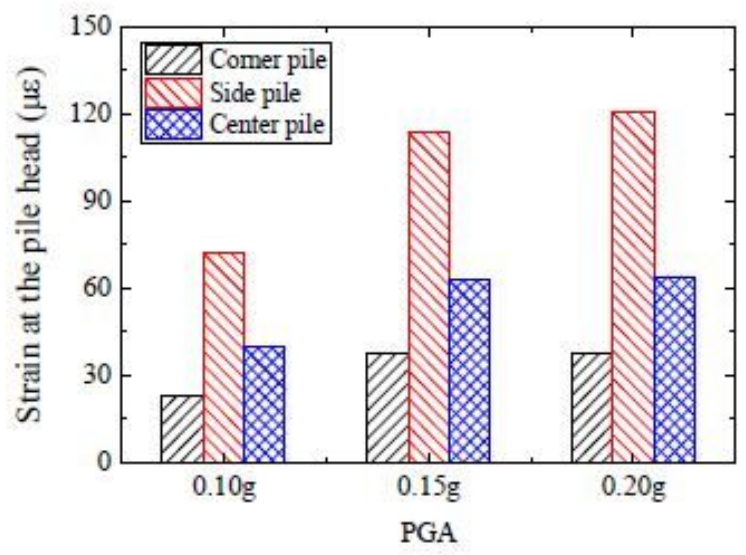

(b) Fixed connection configuration

\section{Figure 25}

Pile group effects of pile-soil-piers with sliding and fixed connections under the synthetic wave

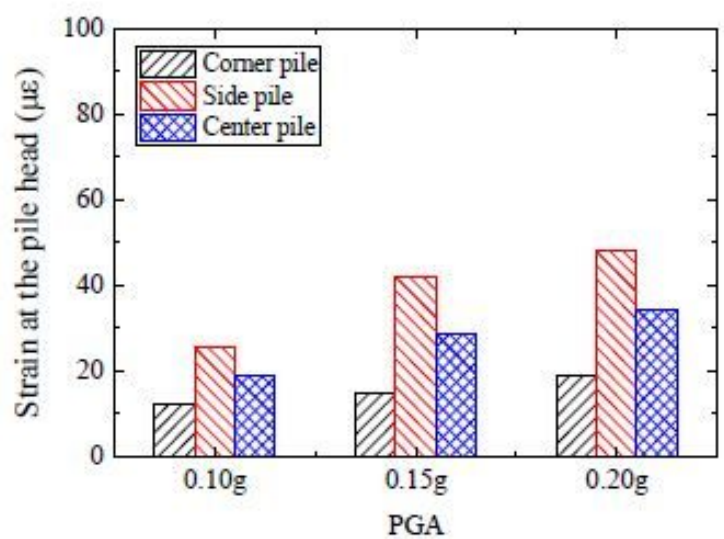

(a) Sliding connection configuration

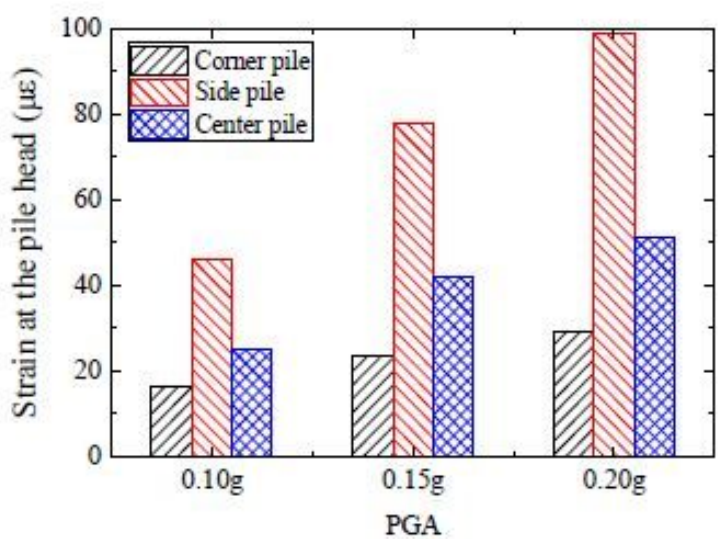

(b) Fixed connection configuration

\section{Figure 26}

Pile group effects of pile-soil-piers with sliding and fixed connections under the El Centro wave 


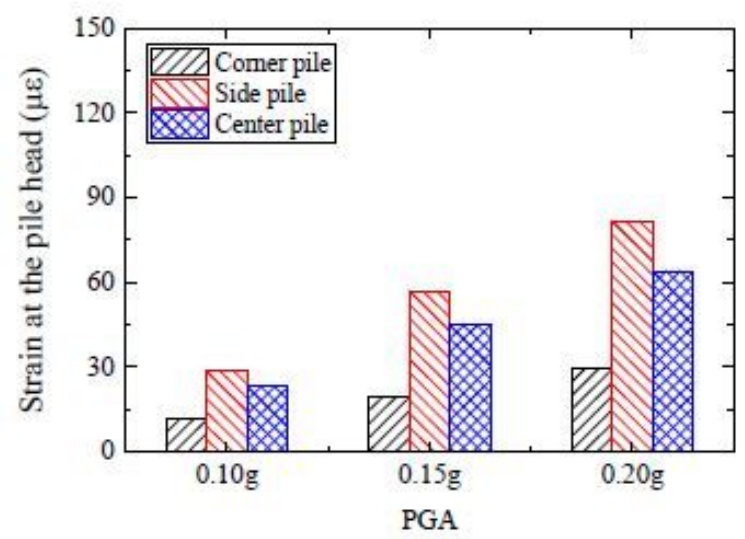

(a) Sliding connection configuration

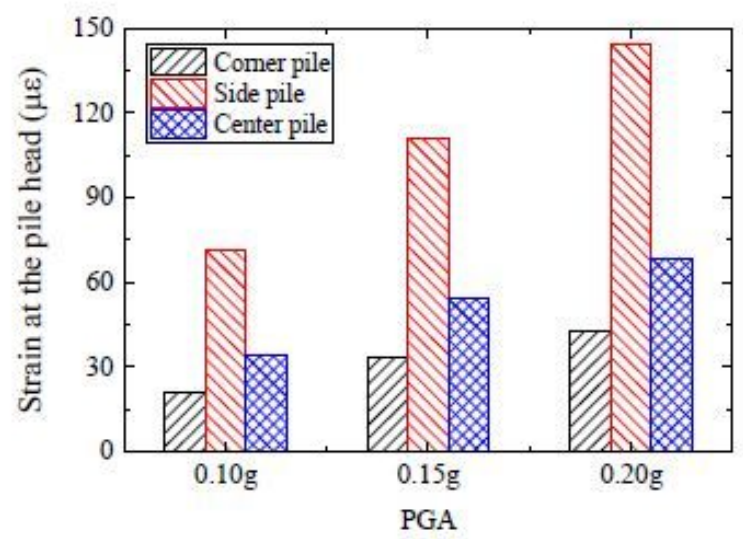

(b) Fixed connection configuration

\section{Figure 27}

Pile group effects of pile-soil-piers with sliding and fixed connections under the Mexico City wave

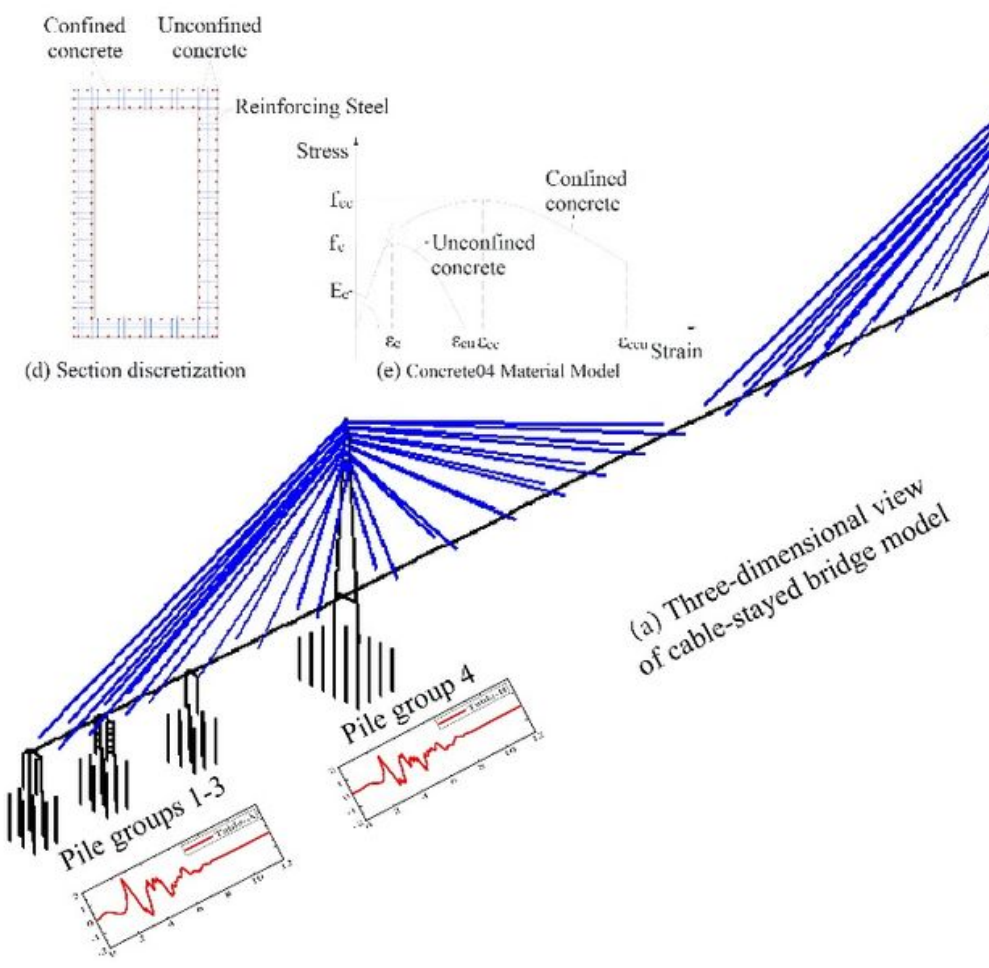

\section{Figure 28}

Numerical model of the bridge model including the pile-soil-piers 


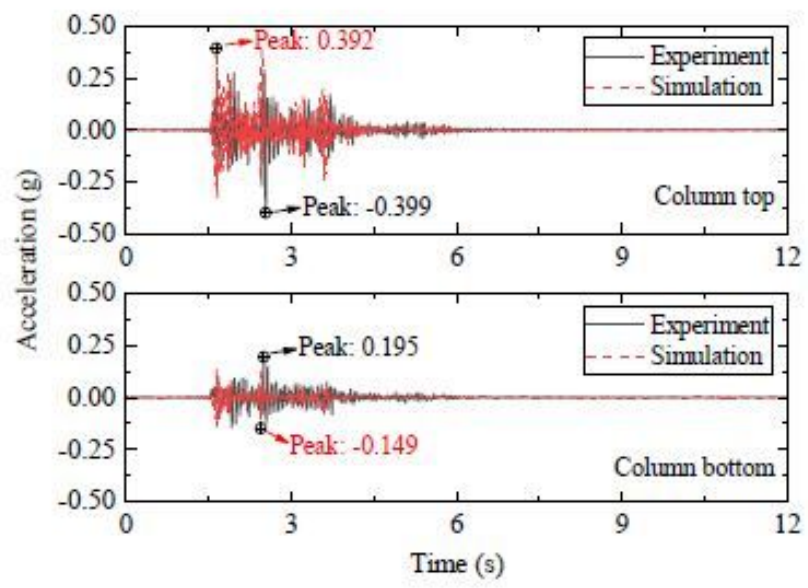

(a) Pile-soil-pier with sliding connections

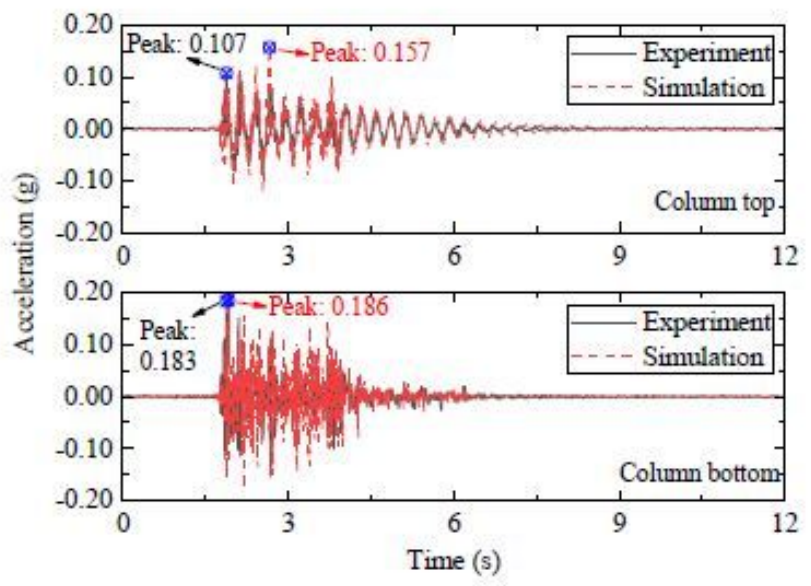

(b) Pile-soil-pier with fixed connections

\section{Figure 29}

Acceleration responses of the column between the experiment and simulation of the pile-soil-pier with sliding and fixed connections for the bridge model under the $0.10 \mathrm{~g}$ El Centro wave

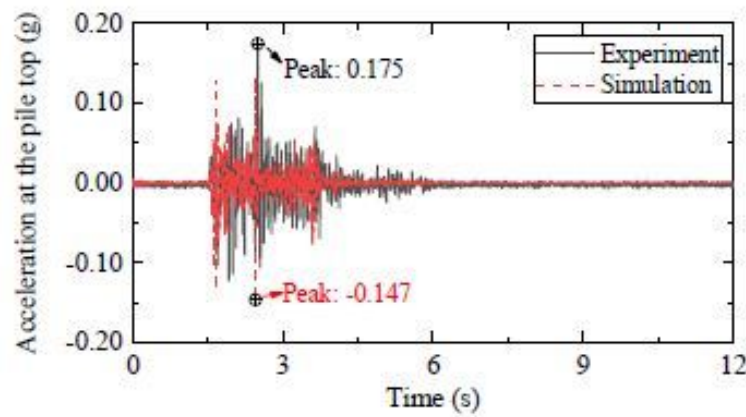

(a) Pile-soil-pier with sliding connections

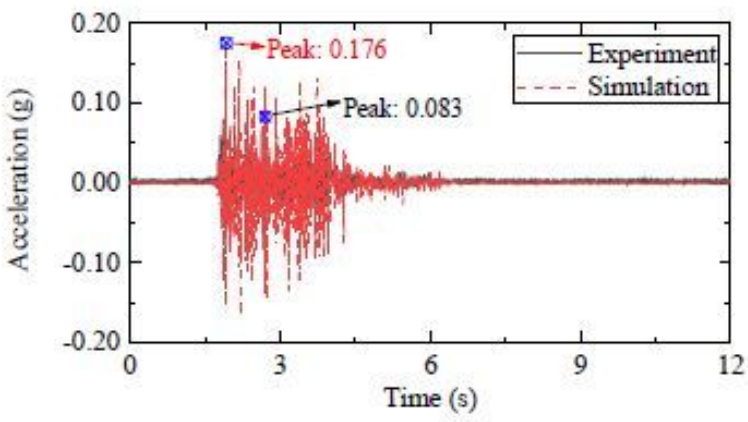

(b) Pile-soil-pier with fixed connections

\section{Figure 30}

Acceleration responses at the pile top between the experiment and simulation of the pile-soil-pier with sliding and fixed connections for the bridge model under the $0.10 \mathrm{~g}$ El Centro wave 


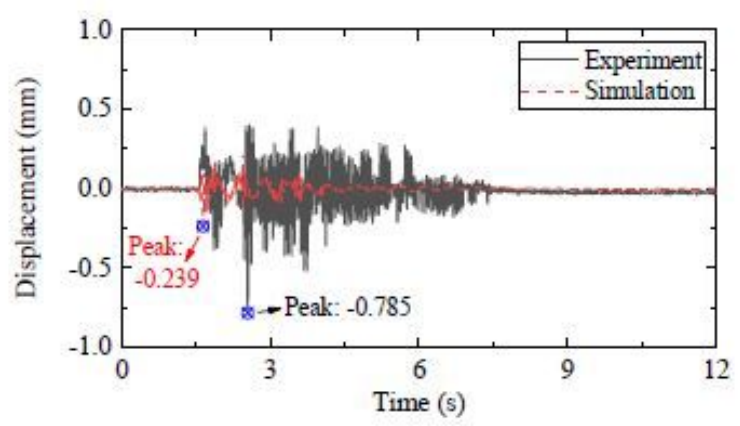

(a) Pile-soil-pier with sliding connections

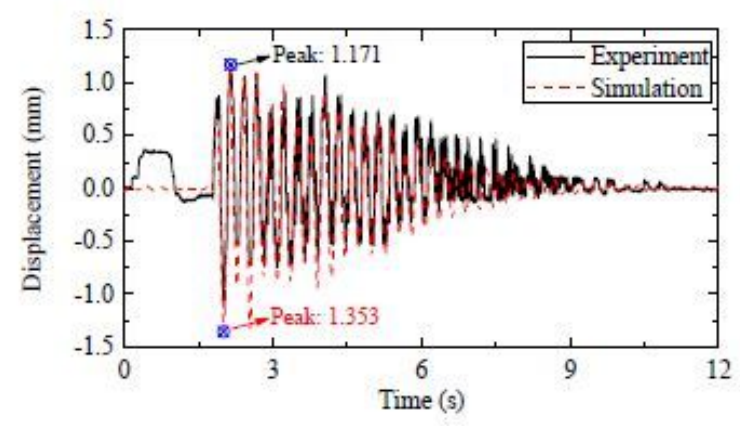

(b) Pile-soil-pier with fixed connections

\section{Figure 31}

Displacement responses at the column top between the experiment and simulation of the pile-soil-pier with sliding and fixed connections for the bridge model under the $0.10 \mathrm{~g}$ El Centro wave 